\title{
Determination of the Role of Berberis spp. in Wheat Stem Rust in China
}

Jie Zhao, State Key Laboratory of Crop Stress Biology for Arid Areas, and College of Plant Protection, Northwest A\&F University, Yangling, Shaanxi 712100, China; Shilei Zhao, College of Plant Protection, Northwest A\&F University; Xianming Chen, United States Department of Agriculture-Agricultural Research Service, Wheat Genetics, Physiology, Quality, and Disease Research Unit, and Department of Plant Pathology, Washington State University, Pullman 99164-6430; Zhiyan Wang, Long Wang, Juanni Yao, and Wen Chen, College of Plant Protection, Northwest A\&F University; and Lili Huang and Zhensheng Kang, State Key Laboratory of Crop Stress Biology for Arid Areas, and College of Plant Protection, Northwest A\&F University

\begin{abstract}
Zhao, J., Zhao, S. L., Chen, X. M., Wang, Z. Y., Wang, L., Yao, J. N., Chen, W., Huang, L. L., and Kang, Z. S. 2015. Determination of the role of Berberis spp. in wheat stem rust in China. Plant Dis. 99:1113-1117.

Previous studies on the relationship of barberry (Berberis spp.) and wheat stem rust suggested that, although some barberry species can serve as alternate hosts for the stem rust fungus Puccinia graminis f. sp. tritici, barberry plants play no role in wheat stem rust development and virulence variation of $P$. graminis f. sp. tritici in China. In the present study, severe rust infections on Berberis shensiana, B. brachypoda, $B$. potaninii, $B$. soulieana, and B. aggregata were observed during field surveys in 2011 and 2012. Through artificial inoculation of wheat seedlings ('Mingxian 169 ') under greenhouse conditions with aeciospores from naturally infected barberry plants, 185 isolates of $P$. graminis f. sp. tritici were obtained. From the 27 selected isolates that were tested on a set of wheat genotypes used to differentiate $P$. graminis f. sp. tritici races in China, 18

races were identified, of which 8 races were new and others were of Chinese 21 and 34 race groups. In addition to the information of virulence or avirulence patterns on the Chinese differentials, none of the races were virulent to resistance gene $\mathrm{Sr} 31$. The virulence frequencies based on individual $\mathrm{Sr}$ genes or differentials ranged from 0 to $96 \%$. Using molecular markers for $P$. graminis f. sp. tritici, 75 of 4,036 samples of single aecia were identified as $P$. graminis f. sp. tritici. The low detectable rate of $P$. graminis f. sp. tritici was verified based on both infection and molecular marker tests. This observation may be correlated with the low levels of wheat stem rust in the surveyed regions. This study shows that $P$. graminis f. sp. tritici can produce new races through sexual reproduction on Berberis spp. in China.
\end{abstract}

Stem rust (or black rust), caused by Puccinia graminis f. sp. tritici Erikss. \& Henning, is one of the most destructive diseases of wheat (Triticum aestivum L.) worldwide (Singh et al. 2006). In China, nine remarkably severe epidemics of stem rust occurred in the springwheat-growing region in northeastern China and winter-wheatgrowing regions, including southeastern China, the Yangtze River region, and the Huai River region from the 1920s to the 1960s, which resulted in significant yield losses in the epidemic years (Li and Zeng 2002). For example, 1 million $\mathrm{kg}$ of wheat grain was lost due to the outbreak of stem rust in Jiangsu and Anhui provinces in 1956. The extensive growth of resistant cultivars over the world has dramatically diminished damage caused by $P$. graminis f. sp. tritici as a significant factor in wheat-growing areas (Roelfs et al. 1992). In China, likewise, great efforts have been made to successfully control wheat stem rust by developing wheat cultivars with resistance since the 1970s (Zhuang 2003). Among the stem rust ( $S r)$ resistance genes, Sr31 has been mostly used in wheat cultivars in China because the gene is linked to $\operatorname{Yr} 9$ for resistance to stripe rust and $P m 8$ to powdery mildew. As the TTKS (or Ug99) race group has emerged in eastern Africa and spread since 1998 (Jin and Sing 2006; Jin et al. 2007), wheat production has become vulnerable to the new virulent races in many wheat-growing countries, including China (He et al. 2008).

Previous studies have demonstrated that the sexual stage of $P$. $g r a-$ minis f. sp. tritici through infection on barberry plants (Berberis spp.) not only generated new races but also led to diverse virulence variations of $P$. graminis f. sp. tritici populations (Jin 2011; Johnson et al. 1932; Lekomtseva et al. 2006; Martens et al. 1989; Newton et al. 1930; Rouse et al. 2009; Stakman et al. 1930; Stakman and Rodenhiser 1958; Waterhouse 1929; Wilcoxson and Paharia 1958). Moreover,

Corresponding author: Z. S. Kang; E-mail: kangzs@nwsuaf.edu.cn

Accepted for publication 23 November 2014.

http://dx.doi.org/10.1094/PDIS-09-14-0928-RE

(c) 2015 The American Phytopathological Society initial infection of the stem rust pathogen on wheat crops can be triggered by aeciospores in regions where susceptible barberry and wheat plants coexist, such as many regions in Australia (Waterhouse 1934), Canada (Johnson and Green 1951), Ethiopia (Lekomtseva et al. 2006), France (Guyot and Massenot 1955), Italy (Sibilia 1936), Spain (Urríes and Cańamas 1952), and the United States (Stakman 1919; Stakman et al. 1934, 1958). For this reason, eradication of susceptible barberry plants by legislation was practiced to uncover significant benefits: reduction of initial inoculum, decrease in the number of races, and stabilization of the pathogen populations in many countries, especially in Europe and North America (Jin 2011; Roelfs 1982; Stakman 1919; Zadoks and Bouwman 1985).

With respect to the association of barberry to wheat stem rust in China, little is known about whether barberry plays a role in providing initial inoculum to trigger primary infection on wheat, or in generating new races of $P$. graminis f. sp. tritici. Wang (1955) obtained $P$. graminis f. sp. tritici uredinial pustules on wheat 'Wugong 7774', after inoculation using aeciospores from Berberis amurensis in the wild in Hebei Province. However, Zhang et al. (1957) challenged the results according to their continuous 3-year investigation in the same region, and suggested that the infection on Wugong 7774 wheat by Wang (1955) might not be caused by aeciospores from barberry but by urediniospores from wheat falling on aecia on barberry leaves. In Qinghai Province, aecia were remarkably abundant on seven species of barberry, including $B$. vernae, $B$. henryana, $B$. thunbergii, B. dubia, B. kansuensis, B. diaphana, and an unidentified Berberis sp. in spring, but aecial samples failed to produce infection on five susceptible wheat cultivars (Wheat Rust Research Group, Northwest Institute of Agricultural Sciences 1958). Zeng and Xue (1963) reported that, although $B$. amurensis serves as an alternate host for $P$. graminis f. sp. tritici, it does not have any effect on epidemics of wheat stem rust in the middle part of northeastern China, and pointed out that the stem rust fungus did not generate diverse races via $B$. amurensis. Although Wang et al. (1958) reported that $P$. graminis f. sp. tritici growing on $B$. amurensis generated two new races (races 9 and 15) by artificial inoculation under laboratory conditions, aeciospores from serious rust-infected $B$. amurensis were not successful 
for producing infection on wheat after inoculation in the middle part of northeastern China. Therefore, it was inferred that B. amurensis plays little to no role in epidemics of wheat stem rust in this region.

In the present study, abundant aecia were observed on several Berberis spp. in Gansu and Shaanxi provinces in China during the surveys in 2011 and 2012. Aecial collections were used to inoculate wheat. The objectives of the present study were to isolate $P$. graminis f. sp. tritici from aecia of barberry and identify $P$. graminis f. sp. tritici races from isolates derived from aeciospores produced on barberry plants using a set of wheat genotypes that are used to differentiate Chinese $P$. graminis f. sp. tritici races and lines carrying important $\mathrm{Sr}$ genes, including $\mathrm{Sr} 31$.

\section{Materials and Methods}

Sample collection and inoculation. During our previous investigations, we found that B. brachypoda, B. potaninii, B. soulieana,

Table 1. Samples of aecia produced on Berberis spp. infected by rust fungi in Gansu and Shaanxi provinces in 2011 and 2012 , and identification of aeciospores as Puccinia graminis f. sp. tritici by inoculation on 'Mingxian 169' wheat in the greenhouse and by polymerase chain reaction (PCR) amplification using primer pairs Puccinia internal transcribed spacer (ITS)3 (5'-ACATCGATGAAGAACACAGT-3') and ITS4 (5'-TCCTCCGCTTATTGATATGC-3')

\begin{tabular}{|c|c|c|c|c|c|c|c|c|c|}
\hline \multirow[b]{4}{*}{ Berberis spp. } & \multirow[b]{4}{*}{ Location } & \multicolumn{8}{|c|}{ Number of } \\
\hline & & \multicolumn{4}{|c|}{ Inoculation } & \multicolumn{4}{|c|}{ PCR } \\
\hline & & \multicolumn{2}{|c|}{ Aecia } & \multicolumn{2}{|c|}{$P$. graminis f. sp. tritici isolates ${ }^{\text {a }}$} & \multicolumn{2}{|c|}{ Aecia } & \multicolumn{2}{|c|}{$P$. graminis f. sp. tritici aecia } \\
\hline & & 2011 & 2012 & 2011 & 2012 & 2011 & 2012 & 2011 & 2012 \\
\hline B. aggregata & Qishou, Tianshui, Gansu & 648 & 370 & 4 & 15 & 500 & 270 & 4 & 11 \\
\hline B. brachypoda & Gangu, Tianshui, Gansu & 545 & 836 & 13 & 23 & 500 & 510 & 1 & 16 \\
\hline B. potaninii & Honghuapu, Feng County, Shaanxi & 742 & 64 & 3 & 2 & $\mathrm{ND}^{\mathrm{b}}$ & 206 & ND & 5 \\
\hline B. shensiana & Yingge, Taibai, Shaanxi & 323 & 1643 & 0 & 66 & 500 & 630 & 6 & 2 \\
\hline B. soulieana & Jiangluo, Hui County, Gansu & 458 & 1024 & 2 & 57 & 500 & 420 & 12 & 18 \\
\hline Total & & 2,716 & 3,937 & 22 & 163 & 2,000 & 2,036 & 23 & 52 \\
\hline
\end{tabular}

a Isolates indicated uredinia of $P$. graminis f. sp. tritici produced on wheat leaves inoculated with aeciospores from a single aecium on Berberis spp.

b ND = no data.

Table 2. Virulence of 27 randomly selected isolates of Puccinia graminis f. sp. tritici recovered from Berberis spp. infected by rust fungi in nature in 2011 and 2012 tested on the Chinese set of wheat differentials consisting of $12 \mathrm{Sr}$ single-gene lines and 6 wheat genotype cultivars as supplementary differentials

\begin{tabular}{|c|c|c|c|c|c|c|c|c|c|c|c|}
\hline \multirow[b]{3}{*}{ Number } & \multirow[b]{3}{*}{ Berberis spp. } & \multicolumn{10}{|c|}{ Chinese differentials $^{\mathbf{a}}$} \\
\hline & & \multicolumn{10}{|c|}{$S r$ single-gene line } \\
\hline & & $S r 5$ & $S r 21$ & Sr9e & $S r 7 b$ & Sr11 & Sr6 & $S r 8 a$ & Sr9g & $S r 36$ & $S r 9 b$ \\
\hline 1 & B. aggregata & $\mathrm{L}$ & $\mathrm{L}$ & $\mathrm{L}$ & $\mathrm{H}$ & $\mathrm{H}$ & $\mathrm{L}$ & $\mathrm{H}$ & $\mathrm{H}$ & $\mathrm{H}$ & $\mathrm{H}$ \\
\hline 2 & B. aggregata & $\mathrm{H}$ & $\mathrm{L}$ & $\mathrm{L}$ & $\mathrm{H}$ & $\mathrm{H}$ & $\mathrm{H}$ & $\mathrm{H}$ & $\mathrm{H}$ & $\mathrm{H}$ & $\mathrm{L}$ \\
\hline 3 & B. aggregata & $\mathrm{H}$ & $\mathrm{H}$ & $\mathrm{L}$ & $\mathrm{H}$ & $\mathrm{L}$ & $\mathrm{H}$ & $\mathrm{H}$ & $\mathrm{H}$ & $\mathrm{L}$ & $\mathrm{L}$ \\
\hline 4 & B. aggregata & $\mathrm{H}$ & $\mathrm{H}$ & $\mathrm{L}$ & $\mathrm{L}$ & $\mathrm{H}$ & $\mathrm{H}$ & $\mathrm{H}$ & $\mathrm{L}$ & $\mathrm{H}$ & $\mathrm{H}$ \\
\hline 5 & B. aggregata & $\mathrm{L}$ & $\mathrm{L}$ & $\mathrm{L}$ & $\mathrm{L}$ & $\mathrm{H}$ & $\mathrm{H}$ & $\mathrm{H}$ & $\mathrm{H}$ & $\mathrm{L}$ & $\mathrm{L}$ \\
\hline 6 & B. aggregata & $\mathrm{H}$ & $\mathrm{H}$ & $\mathrm{L}$ & $\mathrm{L}$ & $\mathrm{L}$ & $\mathrm{H}$ & $\mathrm{H}$ & $\mathrm{H}$ & $\mathrm{L}$ & $\mathrm{L}$ \\
\hline 7 & B. aggregata & $\mathrm{H}$ & $\mathrm{H}$ & $\mathrm{L}$ & $\mathrm{H}$ & $\mathrm{H}$ & $\mathrm{H}$ & $\mathrm{H}$ & $\mathrm{H}$ & $\mathrm{L}$ & $\mathrm{L}$ \\
\hline 8 & B. aggregata & $\mathrm{H}$ & $\mathrm{H}$ & $\mathrm{L}$ & $\mathrm{H}$ & $\mathrm{H}$ & $\mathrm{L}$ & $\mathrm{H}$ & $\mathrm{H}$ & $\mathrm{L}$ & $\mathrm{L}$ \\
\hline 9 & B. brachypoda & $\mathrm{H}$ & $\mathrm{L}$ & $\mathrm{L}$ & $\mathrm{H}$ & $\mathrm{L}$ & $\mathrm{H}$ & $\mathrm{H}$ & $\mathrm{H}$ & $\mathrm{L}$ & $\mathrm{H}$ \\
\hline 10 & B. brachypoda & $\mathrm{H}$ & $\mathrm{L}$ & $\mathrm{L}$ & $\mathrm{H}$ & $\mathrm{L}$ & $\mathrm{H}$ & $\mathrm{H}$ & $\mathrm{H}$ & $\mathrm{L}$ & $\mathrm{H}$ \\
\hline 11 & B. brachypoda & $\mathrm{H}$ & $\mathrm{H}$ & $\mathrm{L}$ & $\mathrm{L}$ & $\mathrm{H}$ & $\mathrm{H}$ & $\mathrm{L}$ & $\mathrm{H}$ & $\mathrm{L}$ & $\mathrm{H}$ \\
\hline 12 & B. brachypoda & $\mathrm{L}$ & $\mathrm{L}$ & $\mathrm{L}$ & $\mathrm{L}$ & $\mathrm{H}$ & $\mathrm{H}$ & $\mathrm{H}$ & $\mathrm{H}$ & $\mathrm{L}$ & $\mathrm{H}$ \\
\hline 13 & B. brachypoda & $\mathrm{H}$ & $\mathrm{H}$ & $\mathrm{L}$ & $\mathrm{L}$ & $\mathrm{H}$ & $\mathrm{H}$ & $\mathrm{H}$ & $\mathrm{H}$ & $\mathrm{L}$ & $\mathrm{H}$ \\
\hline 14 & B. brachypoda & $\mathrm{L}$ & $\mathrm{L}$ & $\mathrm{L}$ & $\mathrm{H}$ & $\mathrm{H}$ & $\mathrm{H}$ & $\mathrm{H}$ & $\mathrm{H}$ & $\mathrm{L}$ & $\mathrm{L}$ \\
\hline 15 & B. brachypoda & $\mathrm{H}$ & $\mathrm{H}$ & $\mathrm{L}$ & $\mathrm{H}$ & $\mathrm{H}$ & $\mathrm{H}$ & $\mathrm{H}$ & $\mathrm{H}$ & $\mathrm{H}$ & $\mathrm{H}$ \\
\hline 16 & B. brachypoda & $\mathrm{L}$ & $\mathrm{H}$ & $\mathrm{L}$ & $\mathrm{H}$ & $\mathrm{L}$ & $\mathrm{H}$ & $\mathrm{H}$ & $\mathrm{H}$ & $\mathrm{H}$ & $\mathrm{L}$ \\
\hline 17 & B. brachypoda & $\mathrm{L}$ & $\mathrm{H}$ & $\mathrm{L}$ & $\mathrm{H}$ & $\mathrm{H}$ & $\mathrm{H}$ & $\mathrm{H}$ & $\mathrm{H}$ & $\mathrm{H}$ & $\mathrm{H}$ \\
\hline 18 & B. brachypoda & $\mathrm{H}$ & $\mathrm{L}$ & $\mathrm{L}$ & $\mathrm{H}$ & $\mathrm{L}$ & $\mathrm{H}$ & $\mathrm{H}$ & $\mathrm{H}$ & $\mathrm{L}$ & $\mathrm{H}$ \\
\hline 19 & B. brachypoda & $\mathrm{H}$ & $\mathrm{L}$ & $\mathrm{L}$ & $\mathrm{H}$ & $\mathrm{L}$ & $\mathrm{H}$ & $\mathrm{H}$ & $\mathrm{H}$ & $\mathrm{L}$ & $\mathrm{H}$ \\
\hline 20 & B. brachypoda & $\mathrm{L}$ & $\mathrm{H}$ & $\mathrm{L}$ & $\mathrm{L}$ & $\mathrm{L}$ & $\mathrm{H}$ & $\mathrm{H}$ & $\mathrm{H}$ & $\mathrm{H}$ & $\mathrm{L}$ \\
\hline 21 & B. brachypoda & $\mathrm{H}$ & $\mathrm{L}$ & $\mathrm{L}$ & $\mathrm{H}$ & $\mathrm{H}$ & $\mathrm{H}$ & $\mathrm{H}$ & $\mathrm{H}$ & $\mathrm{H}$ & $\mathrm{H}$ \\
\hline 22 & B. brachypoda & $\mathrm{H}$ & $\mathrm{H}$ & $\mathrm{L}$ & $\mathrm{H}$ & $\mathrm{H}$ & $\mathrm{H}$ & $\mathrm{H}$ & $\mathrm{H}$ & $\mathrm{L}$ & $\mathrm{L}$ \\
\hline 23 & B. brachypoda & $\mathrm{H}$ & $\mathrm{L}$ & $\mathrm{L}$ & $\mathrm{H}$ & $\mathrm{L}$ & $\mathrm{H}$ & $\mathrm{H}$ & $\mathrm{H}$ & $\mathrm{L}$ & $\mathrm{H}$ \\
\hline 24 & B. brachypoda & $\mathrm{H}$ & $\mathrm{L}$ & $\mathrm{L}$ & $\mathrm{H}$ & $\mathrm{L}$ & $\mathrm{H}$ & $\mathrm{H}$ & $\mathrm{H}$ & $\mathrm{L}$ & $\mathrm{H}$ \\
\hline 25 & B. potaninii & $\mathrm{H}$ & $\mathrm{H}$ & $\mathrm{L}$ & $\mathrm{H}$ & $\mathrm{H}$ & $\mathrm{H}$ & $\mathrm{H}$ & $\mathrm{H}$ & $\mathrm{H}$ & $\mathrm{L}$ \\
\hline 26 & B. potaninii & $\mathrm{H}$ & $\mathrm{L}$ & $\mathrm{L}$ & $\mathrm{H}$ & $\mathrm{L}$ & $\mathrm{H}$ & $\mathrm{H}$ & $\mathrm{H}$ & $\mathrm{H}$ & $\mathrm{H}$ \\
\hline 27 & B. potaninii & $\mathrm{H}$ & $\mathrm{L}$ & $\mathrm{L}$ & $\mathrm{L}$ & $\mathrm{H}$ & $\mathrm{H}$ & $\mathrm{H}$ & $\mathrm{H}$ & $\mathrm{H}$ & $\mathrm{L}$ \\
\hline \multirow{2}{*}{\multicolumn{2}{|c|}{ Virulence frequency $(\%)$}} & 74.1 & 48.1 & 0.0 & 70.4 & 66.7 & 92.6 & 96.3 & 96.3 & 96.3 & 55.6 \\
\hline & & & & & & & & & \multicolumn{3}{|c|}{ (continued on next page) } \\
\hline
\end{tabular}

${ }^{a}$ Chinese differentials for different $P$. graminis f. sp. tritici races include $12 S r$-single gene lines and 6 supplementary genotypes: $S r 5=\mathrm{ISr} 5$-Ra, $S r 21=\operatorname{Triticum}$ monococom derivative, $\operatorname{Sr} 9 e=$ Verstein, $S r 7 b=$ ISr7b-Ra, $S r 11=$ ISr11-Ra, $\operatorname{Sr} 6=$ ISr6-Ra, $S r 8 a=$ ISr8-Ra, $S r 9 g=$ CnSSr9g, $S r 36=$ W2691SrTt-1, Sr9b = W2691Sr9b, Sr30 = BtSr30Wst, Sr17 = Combination VII, Einkorn (Ein., Sr21), Mianzi 52 (M52, Sr17, SrMz, and more undetermined resistance stem rust genes), Minnesota 2761 (M2761, unknown gene), Huadong 6 (H6), Rulofen (Rul., unknown gene), and Orofen (Oro., unknown gene) based on Chen et al. (1994), Roelfs and Martens (1988), and Zhang et al. (1994). "L" indicates low (infection type [IT] 0 to 2) and "H" indicates high (IT 3 to 4), based on the 0 to 4 scale described by Stakman et al. (1962).

b The $S r 31$ single-gene line (Sr31/6*LMPG) was included to determine any possible "Ug99" like races.

c The race was the determined race type of known races or race group of Puccinia graminis f. sp. tritici. 
B. aggregata, and B. shensiana grow extensively in Gansu and Shaanxi provinces, and plants of these species were heavily infected by rust fungi (unpublished data). Aecia generated on plants of different Berberis spp. were similar in color but varied in sizes. Samples of leaves bearing aecia were collected from rust-infected barberry plants in Gansu and Shaanxi (Table 1). Single leaf samples were kept in paper bags $(15$ by 5 by $10 \mathrm{~cm}$ ) in a box with ice packs during surveys, then stored at $4{ }^{\circ} \mathrm{C}$. Aeciospores from a single aecium were used to make an aeciospore suspension with two drops of sterile water (approximate $0.1 \mathrm{ml}$ ) and inoculated on seedlings of 'Mingxian 169' wheat using the method described by Yao et al. (1993). The inoculated wheat plants were incubated at $18^{\circ} \mathrm{C}$ for $16 \mathrm{~h}$ in the dark and for $8 \mathrm{~h}$ with slight light, and moved to a growth chamber with temperatures set to approximately 20 to $25^{\circ} \mathrm{C}$. Uredinial sporulation was observed 10 days after inoculation.

Evaluation of races for virulence. Isolates of $P$. graminis $\mathrm{f}$. sp. tritici derived from barberry plants were inoculated on Mingxian 169 for increasing urediniospores, and on a set of differentials (kindly provided by Dr. Yuanying Cao at Shenyang Agricultural University, Shenyang, Liaoning, China) listed in Table 2 for identification of $P$. graminis $\mathrm{f}$. $\mathrm{sp}$. tritici races using the conditions as described above. The set of Chinese $P$. graminis $\mathrm{f}$. sp. tritici differentials consists of $12 \mathrm{Sr}$ single-gene lines and 6 wheat cultivars used as supplementary differentials (Chen et al. 2007). In addition, a wheat line with Sr31 was also included in the tests to determine its response to the $P$. graminis $\mathrm{f}$. sp. tritici isolates. Infection types were scored based on the 0-to-4 scale described by Stakman et al. (1962) at 10 days after inoculation. Infection types 0 to 2 were treated as resistant and marked as low (L) and 3 to 4 as susceptible and marked as high $(\mathrm{H})$ infection type. If an isolate produced a virulence pattern different from any previously reported race, the test was repeated to confirm the virulence pattern.

Identification of $\boldsymbol{P}$. graminis $\mathrm{f}$. sp. tritici using polymerase chain reaction amplification and sequencing. To identify $P$. graminis f. sp. tritici on barberry leaves bearing aecia, aecial cups produced on single aecium were cut and put into a $2-\mathrm{ml}$ plastic tube with two steel beads ( $5 \mathrm{~mm}$ in diameter) to pulverize using a TissueLyser (Qiagen, Hilden, Germany). Total DNA of an aecium sample was extracted according to the method described by Chen et al. (1993), with slight modification. The fine powder was dispersed in $100 \mu \mathrm{l}$ of extraction buffer (100 mM Tris- $\mathrm{HCl}, \mathrm{pH} 8.0 ; 1.4 \mathrm{mM} \mathrm{NaCl}$; and $55 \mathrm{mM}$ cetyltrimethylammonium bromide) and gently mixed. Then, $20 \mu \mathrm{l}$ of $20 \%$ preheated sodium dodecyl sulfate (final concentration $1 \%$ ) in a water bath with temperature set at $65^{\circ} \mathrm{C}$ was added to the tube. The solution was mixed using a vortex (Genie 2T; Scientific Industries, Inc., NY) and incubated for $30 \mathrm{~min}$ at $65^{\circ} \mathrm{C}$. Proteins were denatured and removed by adding $500 \mu \mathrm{l}$ of Tris- $\mathrm{HCl}$ saturated phenol/ chloroform/isoamyl $(25: 24: 1, \mathrm{vol} / \mathrm{vol} / \mathrm{vol})$, and the purification step was repeated as needed. Liquid phases were separated by centrifuging for $10 \mathrm{~min}$ at $12,000 \mathrm{rpm}$ and $4^{\circ} \mathrm{C}$, the top aqueous phase was transferred to a clean tube, and 2.5 volumes (about $300 \mu$ l) of cold $95 \%$ ethanol was added. After $30 \mathrm{~min}$ of incubation at $4^{\circ} \mathrm{C}$, the solution was centrifuged for $10 \mathrm{~min}$ at $12,000 \mathrm{rpm}$ and $4^{\circ} \mathrm{C}$ to precipitate the nucleic acid. The DNA pellet was rinsed twice with cold $70 \%$ ethanol, dried in a clean bench, and dissolved in $50 \mu$ of Tris-EDTA buffer $(10 \mathrm{mM}$ Tris- $\mathrm{HCl}$ and $1 \mathrm{mM}$ EDTA, $\mathrm{pH}$ 8.0). The DNA samples were checked on $0.8 \%$ agarose gel by electrophoresis for visualization.

A pair of primers, Puccinia internal transcribed spacer (ITS) 3 (5'ACATCGATGAAGAACACAGT-3') and ITS4 (5'-TCCTCCGC TTATTGATATGC-3'), designed by Drs. Meinan Wang and Xianming Chen (United States Department of Agriculture-Agricultural Research Service and Washington States University) to differentiate $P$. graminis f. sp. tritici, $P$. striiformis f. sp. tritici, and $P$. triticina (the causal agent of wheat leaf rust), was used to detect $P$. graminis $\mathrm{f}$. $\mathrm{sp}$. tritici. Based on polymerase chain reaction (PCR) amplification, $P$. graminis $\mathrm{f}$. sp. tritici-positive samples with bands similar in size to a positive check were reamplified. Approximately $100 \mu \mathrm{l}$ of PCR product was sequenced by Beijing Aoke Dingsheng Bio-

Table 2. (continued from preceding page)

\begin{tabular}{|c|c|c|c|c|c|c|c|c|c|c|c|}
\hline \multirow[b]{3}{*}{ Number } & \multirow[b]{3}{*}{ Berberis spp. } & \multicolumn{10}{|c|}{ Chinese differentials ${ }^{\mathbf{a}}$} \\
\hline & & \multicolumn{2}{|c|}{$S r$ single-gene line } & \multicolumn{8}{|c|}{ Supplementary } \\
\hline & & Sr30 & Sr17 & Ein. & M52 & M2761 & H6 & Rul. & Oro. & $S r 31^{\mathrm{b}}$ & Race or race group \\
\hline 1 & B. aggregata & $\mathrm{L}$ & $\mathrm{H}$ & $\mathrm{L}$ & $\mathrm{H}$ & $\mathrm{H}$ & $\mathrm{H}$ & $\mathrm{H}$ & $\mathrm{L}$ & $\mathrm{L}$ & New race 1 \\
\hline 2 & B. aggregata & $\mathrm{L}$ & $\mathrm{L}$ & $\mathrm{L}$ & $\mathrm{L}$ & $\mathrm{H}$ & $\mathrm{H}$ & $\mathrm{L}$ & $\mathrm{L}$ & $\mathrm{L}$ & New race 2 \\
\hline 3 & B. aggregata & $\mathrm{L}$ & $\mathrm{L}$ & $\mathrm{L}$ & $\mathrm{L}$ & $\mathrm{L}$ & $\mathrm{H}$ & $\mathrm{L}$ & $\mathrm{L}$ & $\mathrm{L}$ & 34 \\
\hline 4 & B. aggregata & $\mathrm{H}$ & $\mathrm{L}$ & $\mathrm{L}$ & $\mathrm{L}$ & $\mathrm{L}$ & $\mathrm{H}$ & $\mathrm{L}$ & $\mathrm{L}$ & $\mathrm{L}$ & 34 \\
\hline 5 & B. aggregata & $\mathrm{L}$ & $\mathrm{L}$ & $\mathrm{L}$ & $\mathrm{L}$ & $\mathrm{L}$ & $\mathrm{H}$ & $\mathrm{L}$ & $\mathrm{L}$ & $\mathrm{L}$ & 34 \\
\hline 6 & B. aggregata & $\mathrm{L}$ & $\mathrm{L}$ & $\mathrm{L}$ & $\mathrm{L}$ & $\mathrm{L}$ & $\mathrm{H}$ & $\mathrm{L}$ & $\mathrm{L}$ & $\mathrm{L}$ & 34 \\
\hline 7 & B. aggregata & $\mathrm{L}$ & $\mathrm{L}$ & $\mathrm{L}$ & $\mathrm{L}$ & $\mathrm{L}$ & $\mathrm{H}$ & $\mathrm{L}$ & $\mathrm{L}$ & $\mathrm{L}$ & $34 \mathrm{M}$ \\
\hline 8 & B. aggregata & $\mathrm{L}$ & $\mathrm{L}$ & $\mathrm{L}$ & $\mathrm{H}$ & $\mathrm{L}$ & $\mathrm{H}$ & $\mathrm{L}$ & $\mathrm{L}$ & $\mathrm{L}$ & $21 \mathrm{C} 3$ \\
\hline 9 & B. brachypoda & $\mathrm{L}$ & $\mathrm{H}$ & $\mathrm{L}$ & $\mathrm{L}$ & $\mathrm{L}$ & $\mathrm{L}$ & $\mathrm{L}$ & $\mathrm{L}$ & $\mathrm{L}$ & $34 \mathrm{MKH}$ \\
\hline 10 & B. brachypoda & $\mathrm{L}$ & $\mathrm{L}$ & $\mathrm{L}$ & $\mathrm{L}$ & $\mathrm{L}$ & $\mathrm{L}$ & $\mathrm{L}$ & $\mathrm{L}$ & $\mathrm{L}$ & $34 \mathrm{MKG}$ \\
\hline 11 & B. brachypoda & $\mathrm{L}$ & $\mathrm{L}$ & $\mathrm{L}$ & $\mathrm{H}$ & $\mathrm{L}$ & $\mathrm{H}$ & $\mathrm{L}$ & $\mathrm{H}$ & $\mathrm{L}$ & New race 3 \\
\hline 12 & B. brachypoda & $\mathrm{H}$ & $\mathrm{L}$ & $\mathrm{L}$ & $\mathrm{L}$ & $\mathrm{L}$ & $\mathrm{H}$ & $\mathrm{L}$ & $\mathrm{L}$ & $\mathrm{L}$ & 34 \\
\hline 13 & B. brachypoda & $\mathrm{L}$ & $\mathrm{L}$ & $\mathrm{L}$ & $\mathrm{H}$ & $\bar{L}$ & $\mathrm{H}$ & $\mathrm{L}$ & $\mathrm{H}$ & $\mathrm{L}$ & New race 4 \\
\hline 14 & B. brachypoda & $\mathrm{L}$ & $\mathrm{H}$ & $\mathrm{L}$ & $\mathrm{L}$ & $\mathrm{H}$ & $\mathrm{H}$ & $\mathrm{L}$ & $\mathrm{L}$ & $\mathrm{L}$ & $21 \mathrm{C} 3 \mathrm{CPH}$ \\
\hline 15 & B. brachypoda & $\mathrm{H}$ & $\mathrm{H}$ & $\mathrm{L}$ & $\mathrm{H}$ & $\mathrm{H}$ & $\mathrm{H}$ & $\mathrm{H}$ & $\mathrm{L}$ & $\mathrm{L}$ & New race 5 \\
\hline 16 & B. brachypoda & $\mathrm{L}$ & $\mathrm{L}$ & $\mathrm{L}$ & $\mathrm{H}$ & $\mathrm{L}$ & $\mathrm{H}$ & $\mathrm{L}$ & $\mathrm{L}$ & $\mathrm{L}$ & $21 \mathrm{C} 3$ \\
\hline 17 & B. brachypoda & $\mathrm{L}$ & $\mathrm{L}$ & $\mathrm{L}$ & $\mathrm{L}$ & $\mathrm{H}$ & $\mathrm{H}$ & $\mathrm{L}$ & $\mathrm{L}$ & $\mathrm{L}$ & New race 6 \\
\hline 18 & B. brachypoda & $\mathrm{L}$ & $\mathrm{L}$ & $\mathrm{L}$ & $\mathrm{L}$ & $\mathrm{L}$ & $\mathrm{L}$ & $\mathrm{L}$ & $\mathrm{L}$ & $\mathrm{L}$ & $34 \mathrm{MKG}$ \\
\hline 19 & B. brachypoda & $\mathrm{L}$ & $\mathrm{L}$ & $\mathrm{L}$ & $\mathrm{L}$ & $\mathrm{L}$ & $\mathrm{L}$ & $\mathrm{L}$ & $\mathrm{L}$ & $\mathrm{L}$ & $34 \mathrm{MKG}$ \\
\hline 20 & B. brachypoda & $\mathrm{H}$ & $\mathrm{H}$ & $\mathrm{L}$ & $\mathrm{L}$ & $\mathrm{L}$ & $\mathrm{H}$ & $\mathrm{L}$ & $\mathrm{L}$ & $\mathrm{L}$ & 34 \\
\hline 21 & B. brachypoda & $\mathrm{L}$ & $\mathrm{L}$ & $\mathrm{L}$ & $\mathrm{L}$ & $\mathrm{L}$ & $\mathrm{L}$ & $\mathrm{L}$ & $\mathrm{L}$ & $\mathrm{L}$ & $34 \mathrm{MKR}$ \\
\hline 22 & B. brachypoda & $\mathrm{L}$ & $\mathrm{L}$ & $\mathrm{L}$ & $\mathrm{H}$ & $\mathrm{L}$ & $\mathrm{H}$ & $\mathrm{L}$ & $\mathrm{H}$ & $\mathrm{L}$ & New race 7 \\
\hline 23 & B. brachypoda & $\mathrm{L}$ & $\mathrm{H}$ & $\mathrm{L}$ & $\mathrm{H}$ & $\mathrm{L}$ & $\mathrm{L}$ & $\mathrm{L}$ & $\mathrm{L}$ & $\mathrm{L}$ & $34 \mathrm{C} 1 \mathrm{MKH}$ \\
\hline 24 & B. brachypoda & $\mathrm{L}$ & $\mathrm{H}$ & $\mathrm{L}$ & $\mathrm{H}$ & $\mathrm{L}$ & $\mathrm{H}$ & $\mathrm{L}$ & $\mathrm{L}$ & $\mathrm{L}$ & $34 \mathrm{C} 1 \mathrm{MKH}$ \\
\hline 25 & B. potaninii & $\mathrm{H}$ & $\mathrm{H}$ & $\mathrm{L}$ & $\mathrm{H}$ & $\mathrm{H}$ & $\mathrm{H}$ & $\mathrm{H}$ & $\bar{L}$ & $\mathrm{~L}$ & New race 8 \\
\hline 26 & B. potaninii & $\mathrm{L}$ & $\mathrm{H}$ & $\mathrm{L}$ & $\mathrm{L}$ & $\mathrm{L}$ & $\mathrm{L}$ & $\mathrm{L}$ & $\mathrm{L}$ & $\mathrm{L}$ & $34 \mathrm{C} 2 \mathrm{MKR}$ \\
\hline 27 & B. potaninii & $\mathrm{L}$ & $\mathrm{H}$ & $\mathrm{L}$ & $\mathrm{H}$ & $\mathrm{H}$ & $\mathrm{H}$ & $\mathrm{L}$ & $\mathrm{L}$ & $\mathrm{L}$ & $34 \mathrm{C} 2$ \\
\hline \multicolumn{2}{|c|}{ Virulence frequency (\%) } & 18.5 & 37.0 & 0.0 & 40.7 & 25.9 & 74.1 & 7.4 & 11.1 & 0.0 & $\ldots$ \\
\hline
\end{tabular}


tech Ltd. after checking on $1 \%$ agarose gel for successful amplification. The ITS sequence of selected $P$. graminis f. sp. triticipositive samples were aligned for homology with $P$. graminis f. sp. tritici and other Puccinia fungi data at the National Center for Biotechnology Information (NCBI) database (http://www.ncbi.nlm. nih.gov/).

\section{Results}

Rust infection on Berberis spp. and $\boldsymbol{P}$. graminis f. sp. tritici isolates. In 2011, from 2,716 aecia that were inoculated on leaves of Mingxian 169 wheat, 22 uredinial isolates typical of $P$. graminis f. sp.tritici were obtained from individual aecia, accounting for $0.81 \%$ of the single-aecium samples tested. Except for the aecial samples from $B$. shensiana that failed to generate uredinia, aecia collected from all four other species (B. aggregata, B. brachypoda, B. potaninii, and $B$. soulieana) produced $P$. graminis isolates (Table 1). In 2012, of 3,937 aecia collected from the five Berberis spp., 163 (4.1\%) were $P$. graminis f. sp. tritici. The average of acquisition rate of $P$. graminis f. sp. tritici using artificial inoculation under greenhouse conditions was $2.78 \%$.

Identification of $P$. graminis f. sp. tritici by PCR amplification. $P$. graminis f. sp. tritici was identified from aecial samples collected from four Berberis spp. (B. brachypoda, B. soulieana, B. aggregata, and $B$. shensiana) but not $B$. potaninii. From a total of 2,000 aecia in 2011, 23 (1.15\%) were detected as $P$. graminis f. sp. tritici (Table 1). In 2012, $52(2.25 \%)$ of 2,036 aecia were identified as $P$. graminis $\mathrm{f}$. sp. tritici (Table 1). Although the detectable rate of $P$. graminis f. sp. tritici in 2012 was higher than that of 2011, these rates were very low. The detected rates from B. brachypoda, B. soulieana, and B. aggregata were slightly higher than that of $B$. shensiana. The average detectable rate by the PCR method of the 2 years was $1.86 \%$, which was lower than the $2.78 \%$ by inoculation. No matter which method was used, the rate of $P$. graminis f. sp. tritici infection was quite low, indicating that barberry infection by $P$. graminis $\mathrm{f}$. sp. tritici is relatively infrequent in the sampled regions compared with other Puccinia spp. infection. The sequences of aecial samples, which were submitted to GenBank in our previous study (Zhao et al. 2013), had $>95 \%$ homologies with those of $P$. graminis f. sp. tritici in the NCBI database but had $<90 \%$ homologies with other Puccinia spp. This result, together with typical signs of stem rust produced on wheat plants, showed that the aecia from barberry plants and their derived uredinial isolates were $P$. graminis f. sp. tritici.

$\boldsymbol{P}$. graminis f. sp. tritici races. From the 185 P. graminis f. sp. tritici isolates derived from the aecia on plants of five Berberis spp., 27 were randomly selected to test for virulence on the set of wheat differentials (Table 2). The 27 isolates were identified as 18 races, of which 8 races with 16 isolates were assigned to the race 34 group and 2 races with 3 isolates to the race 21 group. The remaining eight isolates were different from each other and also different from the previously identified races (Cao et al. 1996; Chen et al. 1994, 2007; Han et al. 2010 Huang et al. 1984; Wu 1987; Yao et al. 1993, 1997) and, therefore, were identified as eight new races.

Virulence frequencies. Virulences to $\mathrm{Sr} 5, \mathrm{Sr} 7 b, \mathrm{Sr} 11, \mathrm{Sr} 6, \mathrm{Sr} 8 \mathrm{a}$, $\operatorname{Sr} 9 g, \operatorname{Sr} 36$, and genotype 'Huadong 6' were highly frequent ( $>60 \%)$; those to $\operatorname{Sr} 21, \operatorname{Sr} 9 b, \operatorname{Sr} 17, \mathrm{M} 52$, and $M 2761$ were intermediate (20 to $60 \%)$; and those to $S r 30$, 'Rulofen', and 'Orofen' were low $(<20 \%)$. All 27 tested isolates were avirulent to $\operatorname{Sr} 9 e$, 'Einkorn', and $\operatorname{Sr} 31$ (Table 2). Therefore, no Ug99-like races were detected.

\section{Discussion}

Based on previous reports, 83 species of genus Berberis, 7 species of genus Mahonia, and 1 hybrid of $\times$ Mahoberberis (hybrid between Mahonia spp. and Berberis spp.) were susceptible to P. graminis f. sp. tritici; and 51 species of Berberis, 12 species of Mahonia, and 3 species of $\times$ Mahoberberis were resistant to $P$. graminis (Roelfs 1985). B. aggregata, B. brachypoda, and B. soulieana have been identified to serve as alternate hosts of $P$. graminis $\mathrm{f}$. sp. tritici (Roelfs 1985). In the present study, more than 100 isolates of $P$. graminis f. sp. tritici were obtained from the three Berberis spp., indicating that these Berberis spp. play a role in sexual reproduction of $P$. graminis $f$. sp. tritici under natural conditions, at least in the areas surveyed in the present study. Before the present study, there was no report that $B$. shensiana serves as an alternate host of $P$. graminis f. sp. tritici. In the present study, we obtained $70 P$. graminis f. sp. tritici isolates from $B$. shensiana, showing that this species is susceptible to stem rust. According to the study by Roelfs (1985), B. potaninii is resistant to $P$. graminis f. sp. tritici. However, in the present study, we identified 10 aecia as $P$. graminis f. sp. tritici from samples on $B$. potaninii, indicating that the species is susceptible to stem rust. The difference could be due to different plants of the Berberis spp. or different virulences of the isolates.

Previous studies suggested that some Berberis spp. can serve as alternate hosts for rust fungi on grasses, and some grasses can serve as auxiliary hosts of $P$. graminis f. sp. tritici in China. Zhang et al. (1957) reported $B$. poiretii to be an alternate host of $P$. culmicola, with its uredinial stage on Elymus ciliaris var. ciliaris (synonym: Agropyron ciliaris). Wang et al. (1958) suggested E. sibiricus (synonym: Clinelymus sibiricus) as an auxiliary host of $P$. graminis $\mathrm{f}$. sp. tritici. In the present study, some of the aecia collected from barberry plants could be stem rust or stripe rust fungi on grasses because they could not infect Mingxian 169. More studies are needed to identify all rust species and formae speciales and their relative frequencies on Berberis spp.

In the recent years, some races of the $21 \mathrm{C} 3(21 \mathrm{C} 3 \mathrm{CTH}, 21 \mathrm{C} 3 \mathrm{CFH}$, and $21 \mathrm{C} 3 \mathrm{CPH})$ and $34(34 \mathrm{MKG})$ race groups were detected, while other races (21C3CKH, 21C3CKR, and 21C3CTR) of the $21 \mathrm{C} 3$ race group, which occurred in high frequencies in the early 1990s (Yao et al. 1993), were not detected (Han et al. 2010) in wheat fields. In the present study, most isolates tested were of the 21 or 34 race groups. The 34 race group was more predominant than the 21 race group, which was in contrast to the previous reports on race groups from isolates collected from wheat (Han et al. 2010; Yao et al. 1997). This result was inconsistent with the previous reports that race groups 34 and 21 were predominant in recent decades in China (Chen et al. 1994; Han et al. 2010; Huang et al. 1984; Yao et al. 1997) (Y. Y. Cao, personal communication) (Table 2). Races that are virulent to Rulofen and Orofen wheat were first identified in the late 1970s (Cao et al. 1996; Huang et al. 1984). However, no races virulent to Rulofen or Orofen were detected after the 1970s (Han et al. 2010; Wang et al. 1958; Yao et al. 1993, 1997) (Y. Y. Cao, personal communication). Importantly, Rulofen and Orofen are good resistance resources to be used for breeding wheat cultivars against leaf rust and stem rust. Therefore, races virulent to Rulofen and Orofen detected on barberry plants are potential threats to wheat production in China.

The present study demonstrates that Berberis spp. can generate new races under natural conditions and may play a role in virulence variation of the $P$. graminis f. sp. tritici population in China. This study may change the previous thought that barberry does not play a role in generating virulence variation in the $P$. graminis $\mathrm{f}$. sp. tritici population in China (Wang et al. 1958; Zhang et al. 1957; Zeng and Xue 1963). However, more studies are needed to determine the direct relationship of a sexually reproduced population with the populations of $P$. graminis f. sp. tritici in epidemic regions of wheat stem rust, because the present study was conducted in Gansu and Shaanxi provinces, where the disease is not a major problem.

In the present study, we observed differences between Einkorn ( $S r 21)$ and the $S r 21$ single-gene line in reaction to the $P$. graminis f. sp. tritici isolates. Such differences were also observed in the past decades (Y. Y. Cao, personal communication). Wu (1987) reported virulence of races 17 and 19 on Einkorn but did not detect virulence to the $S r 21$ gene line in the tests of more than 10,000 isolates collected from wheat fields from 1959 to 1985. A significant virulence frequency $(59.5 \%$ ) of the $\operatorname{Sr} 21$ ('W3586' wheat) virulence was reported by Chen et al. (1994) but not in the collections of 2007 to 2008 (Han et al. 2010). The differences indicate that Einkorn and the $S r 21$ "single-gene" line may have additional race-specific resistance genes, which may not be detected by races in other countries. Further studies are needed to test the hypothesis.

The present study shows that $P$. graminis f. sp. tritici is able to infect several Berberis spp. and the pathogen is able to generate more diverse races on alternate hosts in Gansu and Shaanxi provinces of northwestern China. Stem rust occurs in these provinces but usually does not cause significant damage on wheat, which may be due to the 
fact that the winter wheat is harvested early (primarily in June). The early harvest may not leave enough time for stem rust to develop into large-scale epidemics. In addition, infection of barberry plants by $P$. graminis f. sp. tritici is low, as detected in the present study. The low infection on barberry that generates low amounts of inoculum for infection of wheat and the short growth period of wheat crops may explain the relatively low level of stem rust in the region compared with stripe rust, the most destructive disease of wheat crops in the region. In a previous study, we also found that barberry infection by the stripe rust pathogen ( $P$. striiformis $\mathrm{f}$. sp. tritici) was also low (Zhao et al. 2013). The low frequencies of both $P$. graminis f. sp. tritici and $P$. striiformis f. sp. tritici indicate that other Puccinia spp. and formae speciales may infect barberry plants, as discussed above. More studies are needed to determine these species and their relationships to rusts on grasses, as well as the role of $P$. graminis $\mathrm{f}$. sp. tritici aeciospores generated on barberry plants in the annual stem rust occurrence on cereal crops.

\section{Acknowledgments}

This study was supported by the National Basic Research Program of China (number 2013CB127700), the Earmarked Fund for Modern Agroindustry Technology Research System (number CARS-3-1-11), the Nature Science Foundation of China (number 31271986), International Science \& Technology Cooperation Program of China (number 2011DFG32990), and the 111 Project from the Ministry of Education of China (B07049).

\section{Literature Cited}

Cao, Y. Y., Yao, P., Liu, W. Z., and Wu, Y. S. 1996. Pathogenic spectrum analysis of 21C3CTR of Puccinia graminis f. sp. tritici in China. J. Shenyang Agric. Univ. 27:26-30.

Chen, W. Q., Hu, C. C., and Xie, S. X. 1994. Virulence genes of Puccinia graminis f. sp. tritici population in China. Acta Phytophylac. Sin. 21:103-107.

Chen, W. Q., Liu, T. G., Chen, J. L., and Xu, S. C. 2007. Part 3: Rule for resistance evaluation of wheat to stem rust [Puccinia graminis (Pers.) f. sp. tritici Eriks. et Henn.] Pages 1-10 in: Rules for Resistance of Wheat to Disease and Insect Pests (NY/T 1443.3-2007), Ministry of Agriculture, Beijing.

Chen, X. M., Line, F. R., and Leung, H. 1993. Relationship between virulence variation and DNA polymorphism in Puccinia striiformis. Phytopathology 83:1489-1497.

Guyot, L., and Massenot, M. 1955. Observations and experiments on black rust of cereals during the years 1951 to 1953. Ann. Inst. Natl. Rech. Agron. Ser. C 6:89-118.

Han, J. D., Cao, Y. Y., and Sun, Z. G. 2010. Race dynamics of Puccinia graminis f. sp. tritici in China and the virulence of CIMMYT wheat germplasm resistant to Ug99. J. Triticeae Crops 30:163-166.

He, Z. H., Xian, X. C., and Chen, W. Q. 2008. Breeding for resistance to new race Ug99 of stem rust pathogen. J. Triticeae Crops 28:170-173.

Huang, Z. T., Liu, W. Z., Li, S. F., and Wu, Y. S. 1984. Identification and pathogenicity of new race 34C4 of Puccinia graminis f. sp. tritici. Sci. Agric. Sin. 1:79-80.

Jin, Y. 2011. Role of Berberis spp. as alternate hosts in generating new races of Puccinia graminis and P. striiformis. Euphytica 179:105-108.

Jin, Y., and Sing, R. 2006. Resistance to recent eastern African stem rust isolates with virulence to $S r 31$ in U.S. wheat. Plant Dis. 90:476-480.

Jin, Y., Singh, R. P., Ward, R. W., Wanyera, R., Kinyua, M., Njau, P., Fetch, T., Pretorius, Z. A., and Yahyaoui, A. 2007. Characterization of seedling infection types and adult plant infection responses of monogenic $\mathrm{Sr}$ gene lines to race TTKS of Puccinia graminis f. sp. tritici. Plant Dis. 91:1096-1099.

Johnson, T., and Green, G. J. 1951. The varieties of stem rust, Puccinia graminis Pers., occurring on barberry in Eastern Canada. Can. J. Bot. 29:1-9.

Johnson, T., Newton, M., and Brown, A. M. 1932. Hybridization of Puccinia graminis tritici with Puccinia graminis secalis and Puccinia graminis agrostidis. Sci. Agric. 13:141-153.

Lekomtseva, S. N., Volkova, V. T., Zaitseva, L. G., and Chaika, M. N. 2006. Races of Puccinia graminis f. sp. tritici in the Russian Federation in 2004. Annu. Wheat Newsl. 52:100-101.

Li, Z. Q., and Zeng, S. M. 2002. Page 379 in: Wheat Rusts in China. China Agriculture Press, Beijing

Martens, J. W., Dunsmore, K. M., and Harder, D. E. 1989. Incidence and virulence of Puccinia graminis in Canada on wheat and barley in 1988. Can. J. Plant Pathol. 11:424-430.

Newton, M., Johnson, T., and Brown, A. M. 1930. A preliminary study on the hybridization of physiologic forms of Puccinia graminis tritici. Sci. Agric. 10:721-731.

Roelfs, A. P. 1982. Effects of barberry eradication on stem rust in the United States. Plant Dis. 66:177-181
Roelfs, A. P. 1985. Wheat and rye stem rust. Pages 26-30 in: The Cereal Rusts, Volume II: Diseases, Distribution, Epidemiology, and Control. A. P. Roelfs and R. W. Bushnell, eds. Academic Press, London.

Roelfs, A. P., and Martens, J. W. 1988. An international system of nomenclature of Puccinia graminis f. sp. tritici. Phytopathology 78:526-533.

Roelfs, P. A., Singh, R. P., and Saari, E. E. 1992. Rust Disease of Wheat: Concepts and Methods of Disease Management. CIMMYT, Mexico D.F.

Rouse, M. N., Stoxen, S., Chen, X., Szabo, L. J., and Jin, Y. 2009. Diverse stem rust races found in a single field in Washington, USA. (Abstr.) Phytopathology 99:S111

Sibilia, C. 1936. Ricerche sulle ruggini dei cereali. VI, La specializzazione della 'Puccinia graminis tritici Erikss. et Henn.' Boll. R. Staz. Pat. Veg. 16:95-98. In Italian.

Singh, R. P., Hodson, D. P., Jin, Y., Huerta-Espino, J., Kinyua, M. G., Wanyera, R., Njau, P., and Ward, R. W. 2006. Current status, likely migration and strategies to mitigate the threat to wheat production from race Ug99 (TTKS) of stem rust pathogen. Persp. Agric. Vet. Sci. Nutr. Nat. Res. 1:1-13.

Stakman, E. C. 1919. The black stem rust and the barberry. Pages 75-100 in: U.S. Department of Agriculture Year Book.

Stakman, E. C., Levin, M. N., and Cotter, R. U. 1930. Origin of physiologic forms of Puccinia graminis through hybridization and mutation. Sci. Agric. 10:707-720.

Stakman, E. C., Levine, M. N., Cotter, R. U., and Hines, L. 1934. Relation of barberry to the origin and persistence of physiologic forms of Puccinia graminis. J. Agric. Res. 48:953-970.

Stakman, E. C., and Rodenhiser, H. A. 1958. Race 15B of wheat stem rust-What it is and what it means. Adv. Agron. 10:143-165.

Stakman, E. C., Stewart, D. M., and Loegering, W. Q. 1962. Identification of physiologic races of Puccinia graminis var. tritici. U.S. Dep. Agric. Agric. Res. Serv. E617 (rev.)

Urríes, M. J., and Cańamas, R. 1952. Razas fisiológicas de "Puccinia graminis tritici" y "P. rubigo-vera tritici" en Espana, en el períod 1950-1952. Bol. Inst. Nac. Inv. Agron. 27:593-616.

Wang, J. S. 1955. Experimental results of inoculation on spring wheat with aeciospores from Berberis amurensis Rupr. Agric. Sci. Bull. 1:54.

Wang, Y. Z., Wang, H. R., Zeng, G. R., Zhang, G. C., and Xue, L. X. 1958. Primary study on association of Berberis amurensis Rupr. with wheat stem rust in the middle part of Northeastern China. Northeast Agric. Sci. Bull. 3:77-88.

Waterhouse, W. L. 1929. A preliminary account of the origin of two new Australian physiologic forms of Puccinia graminis tritici. Linn. Soc. N. S. Wales Proc. 54:96-106.

Waterhouse, W. L. 1934. Pages 16-18 in: Australian Rust Studies IV. Natural Infection of Barberries by Black Stem Rust in Australia. The Linnean Society of New South Wales, Sydney, Australia.

Wheat Rust Research Group, Northwest Institute of Agricultural Sciences. 1958. Study on the association of seven barberry species with wheat stem rust in Qinghai Province. J. Northwest Agric. Sci. (later renamed Shaanxi J. Agric. Sci.) 3:190-194.

Wilcoxson, R. D., and Paharia, K. D. 1958. A study of the progeny from the selffertilization of race 111 of Puccinia graminis var. tritici. Phytopathology 48: 644-645.

Wu, Y. S. 1987. Twenty year's racial identification and fluctuation analysis of Puccinia graminis var. tritici in China. J. Shenyang Agric. Univ. 18:105-138.

Yao, P., Cao, Y. Y., Jia, X. L., Zhou, Z. J., and Wu, Y. S. 1993. Dynamics of races and virulence of Puccinia graminis f. sp. tritici in China in 1992. Plant Prot. 19: 6-8.

Yao, P., Cao, Y. Y., Liu, W. Z., and Wu, Y. S. 1997. Race population trend of Puccinia graminis f. sp. tritici in 1990-1994 in China. Acta Phytophylac. Sin. 24:297-302.

Zadoks, J. C., and Bouwman, J. J. 1985. Epidemiology in Europe. Pages 329-369 in: The Cereal Rusts, II: Diseases, Distribution, Epidemiology, and Control. A. P. Roelfs and W. R. Bushnell, eds. Academic Press, London.

Zeng, G. R., and Xue, L. X. 1963. Study on relation of Berberis amurensis Rup. to occurrence of wheat stem rust in the middle of North China. J. Plant Prot. 2. 47-55.

Zhang, G. C., Zeng, G. R., and Xue, L. X. 1957. Report on association of Berberis poiretii Sch. with wheat stem rust. Northeast Agric. Sci. Bull. 4:102-107.

Zhang, S. S., Zhou, Z. J., and Yang, T. 1994. Monosomic analysis of the stem rust resistant genes in common wheat variety Mianzi 52, a Chinese differential host for Puccinia graminis f. sp. tritici. Sci. Agric. Sin. 27:28-32.

Zhao, J., Wang, L., Wang, Z. Y., Chen, X. M., Zhang, H. C., Yao, J. N., Zhan, G. M., Chen, W., Huang, L. L., and Kang, Z. S. 2013. Identification of eighteen Berberis species as alternate hosts of Puccinia striiformis f. sp. tritici and virulence variation in the pathogen isolates from natural infection of barberry plants in China. Phytopathology 103:927-934.

Zhuang, Q. S. 2003. Pages 264-310 in: Chinese Wheat Improvement and Pedigree Analysis. China Agriculture Press, Beijing. 